\title{
REDUCTION OF MICROORGANISMS IN MARINATED POULTRY BREAST USING OREGANO ESSENTIAL OIL AND POWER ULTRASOUND
}

\author{
M.I. Piñona ${ }^{\mathrm{a}}$, A.D. Alarcon-Rojo ${ }^{\mathrm{a} *}$, A.L. Renteria ${ }^{\mathrm{a}}$, G. MendeZ ${ }^{\mathrm{a}}$ and H. Janacua-Vidales ${ }^{\mathrm{b}}$ \\ ${ }^{a}$ Facultad de Zootecnia y Ecología, Universidad Autónoma de Chihuahua, Perif. Fco. R. Almada km 1, Chihuahua, \\ Chih., 31453. Mexico \\ ${ }^{b}$ Departamento de Ciencias Veterinarias, Instituto de Ciencias Biomédicas, Universidad Autónoma \\ de Ciudad Juárez, Henri Dunant 4016, Ciudad Juárez, Chih., 32310. Mexico
}

(Received: 28 February 2014; accepted: 28 August 2014)

\begin{abstract}
Marinated chicken meat is an ideal substrate for the growth of microorganisms. The aim of this study was to determine the effect of high-intensity ultrasound on the microbial flora of chicken meat marinated in oregano oil. Three concentrations of oregano oil $(0 \%, 0.1 \%$, and $0.3 \%)$ and two types of marination (traditional and highintensity ultrasound) were tested. Microorganisms were enumerated immediately after marination and on 7, 14, and 21 days of chilled storage. Marination in oregano oil resulted in significant differences $(\mathrm{P}<0.05)$ in the numbers of anaerobic, lactic acid bacteria, and mesophiles. Ultrasound with $0.1 \%$ OEO did not show any effect on the three types of bacteria. The treatment with $0.3 \%$ oregano oil and ultrasound had the greatest effect on controlling microbial growth. Therefore, a combination of ultrasound and oregano oil is the most appropriate option for reducing the growth of mesophilic, anaerobic, and lactic acid bacteria in vacuum-packed marinated chicken breasts during chilled storage.
\end{abstract}

Keywords: microbiological quality, oregano essential oil, poultry meat, power ultrasound, marinated meat, antimicrobials

The growth of microorganisms in animal products is a crucial issue for the food industry, because the shelf-life of any food is determined primarily by its microbial content. Thus, control of the bacterial microflora is essential for increasing the shelf life and reducing economic losses. Various methods are employed to control microbial growth in chicken (e.g., vacuum packaging, the addition of preservatives and acidic agents (marination), and heat). Recently, it was shown that essential oils derived from herbs and spices, such as cloves, coriander, and oregano, can help to reduce significantly the growth of microorganisms in various types of food products (BURT, 2004). Essential oils are naturally occurring chemical preservatives, so they are considered safe, and their acceptance by potential consumers is high (NYCHAS, 1995). In particular, the bactericidal activity of oregano essential oil (OEO) is attributed mainly to its major components, thymol and carvacrol. The bactericidal effect of OEO is mediated by damage to the bacterial cell membrane, which affects the $\mathrm{pH}$, ionic balance (LAMBERT et al., 2001), and permeability (BURT, 2004). It has also been suggested that OEO depletes the ATP reserves (Oussalah et al., 2006). BurT (2004) mentions that OEO is one of the most effective natural compounds for microbiological control in meat products, including chicken (OrAL et al., 2009) and beef (SKANDAMIS et al., 2002). Furthermore, several authors have shown that the combination of OEO with other preservation methods further

\footnotetext{
* To whom correspondence should be addressed.

Phone: +52614-434-0303; fax: +52614-434-0345; e-mail: aalarcon@uach.mx
} 
enhances the control of microbial growth (CHOULIARA et al., 2007). Non-thermal treatments, such as high-intensity ultrasound, can also help to control microbial growth in foods, such as chicken meat (Haughton et al., 2010), milk (CAMERon, 2007), water (Hunter et al., 2008), fruit juices (CHENG et al., 2007), and vegetables (Zноu et al., 2009). The antibacterial action of high-intensity ultrasound is attributable to the phenomenon of cavitation (CAMERON, 2007). By contrast, low-intensity ultrasound does not cause sufficient cellular damage to eliminate microorganisms, because it produces too few bubbles by cavitation (JørGENSEN et al., 2008). However, although it has been shown that the addition of OEO to meat is an effective microbial control method, its use has been limited because of its intense flavour (CHOULIARA et al., 2007). However, OEO could maintain microbiological control without affecting the taste of food if used at an appropriate concentration (GovarIS et al., 2010). The objective of the present study was to determine the effects of high-intensity ultrasound combined with $\mathrm{OEO}$ on the microbial flora of marinated chicken breasts.

\section{Materials and methods}

\subsection{Samples and treatments}

Ninety chicken breasts were obtained from commercial sources and used in this study. The meat samples were assigned randomly to one of six different treatments: T1, Control; T2, Ultrasound (US); T3, 0.1\% Oregano essential oil (OEO); T4, US + 0.1\% OEO; T5, 0.3\% OEO; and T6, US + 0.3\% OEO.

The samples subjected to traditional marination and traditional marination with 0.1 and $0.3 \%$ OEO were dipped in brine for 7,14 , and 21 days and stored aerobically at $4{ }^{\circ} \mathrm{C}$. The samples that received ultrasound treatments were marinated in an ultrasonic bath for $50 \mathrm{~min}$ at a frequency of $60 \mathrm{kHz}$ and a power level of $40 \mathrm{~W}$. All of the marinated samples were dipped individually in $125 \mathrm{ml}$ of brine, which contained $0.045 \mathrm{~g}$ of garlic powder, $0.15 \mathrm{~g}$ of ground pepper, $0.9 \mathrm{~g}$ of sodium chloride, $0.015 \mathrm{~g}$ of onion powder, $0.15 \mathrm{~g}$ of citric acid, 0.06 $\mathrm{g}$ of sodium benzoate, $0.15 \mathrm{~g}$ of phosphates, $0.12 \mathrm{ml}$ of liquid smoke, $7.47 \mathrm{ml}$ of olive oil, $14.94 \mathrm{ml}$ of vegetable oil, and $11.95 \mathrm{ml}$ of apple cider vinegar. The OEO contained $60 \mathrm{~g} \mathrm{~kg}^{-1}$ of carvacrol and $55 \mathrm{~g} \mathrm{~kg}^{-1}$ of thymol (Agrodonpablo ${ }^{\circledR}$, Chihuahua, Mexico). After marination, $1 \mathrm{ml}$ aliquots of the brine were used for microbiological analyses. The meat was then vacuumpacked and stored at $4{ }^{\circ} \mathrm{C}$. The packs were opened aseptically on days 7,14 , and 21 , and $1 \mathrm{ml}$ aliquots were taken before the meat was vacuum-packed again.

\subsection{Microbiological analysis}

The samples were subjected to tenfold serial dilution in Maximum Recovery Diluent (Difco) and analysed by surface plating ( $0.1 \mathrm{ml}$ of each dilution) on both plate count agar (Difco) and de Man, Rogosa, Sharpe agar (Difco). Anaerobic bacteria and lactic acid bacteria (LAB) were incubated anaerobically at $25^{\circ} \mathrm{C}$ for 3 days. Mesophiles were incubated aerobically at $35^{\circ} \mathrm{C}$ for 3 days. The colony forming units per millilitre $\left(\mathrm{CFU} \mathrm{ml}{ }^{-1}\right)$ were transformed into logarithmic scale units $\left(\log _{10} \mathrm{CFU} \mathrm{ml}{ }^{-1}\right)$.

\subsection{Statistical analysis}

The data were analysed with ANOVA procedure of SAS (2006), using the following statistical model: $\mathrm{y}_{\mathrm{ij}}=\mu+\mathrm{T}_{\mathrm{i}}+\delta_{\mathrm{j}}+(\mathrm{T} \delta)_{\mathrm{ij}}+\varepsilon_{\mathrm{ij}}$; where $\mathrm{y}_{\mathrm{ij}}=$ variables measure in chicken breasts (by count of 
microorganisms) the effect of the $i^{\text {th }}$ treatment in $j^{\text {th }}$ day; $\mu=$ general mean; $T_{i}=$ fixed effect of the $i^{\text {th }}$ treatment; $\delta_{j}=$ effect in the $j^{\text {th }}$ day $(0,7,14$, and 21$) ;(\mathrm{T} \delta)_{\mathrm{ij}}=$ fixed effect of the interaction between the $i^{\text {th }}$ treatment and the $j^{\text {th }}$ day; $\varepsilon_{\mathrm{ij}}=$ random error normally distributed with zero mean and variance $\sigma^{2}\left(\varepsilon_{\mathrm{ij}} \sim \mathrm{N}\left(0, \sigma^{2}\right)\right)$. When the effect of the treatment was significant between days $(\mathrm{P} \leq 0.05)$, the lowest significant difference (LSD) was used to compare the $\log _{10} \mathrm{CFU} \mathrm{m}{ }^{-1}$ means.

\section{Results and discussion}

\subsection{Anaerobic bacteria}

This work aimed to study the effect of high-intensity ultrasound combined with OEO on the microbial flora of marinated chicken breasts. There were significant differences $(\mathrm{P}<0.05)$ in the growth of anaerobic bacteria only at day seven, when ultrasound treatment combined with $0.3 \%$ OEO gave the lowest microbial count (Table 1). The OEO treatment in itself did not have any effect $(\mathrm{P}>0.05)$ on the growth of anaerobic bacteria either in 0.1 or $0.3 \%$, the only evident effect was observed when $0.3 \%$ OEO was combined with US (T6). These results agree with a previous study by JUNEJA and FRIEDMAN (2007), who found that the number of anaerobic bacteria and their spores did not decrease significantly after adding $\leq 0.1 \%$ OEO to fresh chicken, whereas the addition of higher concentrations inhibited or reduced microbial growth.

Table 1. Anaerobe count $\left(\log _{10} \mathrm{CFU} \mathrm{ml} \mathrm{m}^{-1} \pm\right.$ standard error) recovered from chicken breasts treated with ultrasound and oregano essential oil (number of replicates per treatment: 15)

\begin{tabular}{|c|c|c|c|c|}
\hline \multirow[t]{2}{*}{ Treatments } & \multicolumn{4}{|c|}{ Storage time (days) } \\
\hline & 0 & 7 & 14 & 21 \\
\hline $\mathrm{T} 1$ & $3.89 \pm 0.31^{\mathrm{B}}$ & $4.62 \pm 0.32^{\mathrm{abB}}$ & $5.29 \pm 0.36^{\mathrm{B}}$ & $6.11 \pm 0.32^{\mathrm{A}}$ \\
\hline $\mathrm{T} 2$ & $4.35 \pm 0.31^{\mathrm{B}}$ & $4.21 \pm 0.35^{\mathrm{abB}}$ & $5.18 \pm 0.36^{\mathrm{AB}}$ & $5.34 \pm 0.32^{\mathrm{A}}$ \\
\hline $\mathrm{T} 3$ & $3.54 \pm 0.30^{\mathrm{C}}$ & $3.54 \pm 0.36^{\mathrm{bcBC}}$ & $4.40 \pm 0.36^{\mathrm{B}}$ & $5.89 \pm 0.35^{\mathrm{A}}$ \\
\hline $\mathrm{T} 4$ & $4.28 \pm 0.30^{\mathrm{C}}$ & $5.39 \pm 0.31^{\mathrm{aB}}$ & $5.74 \pm 0.36^{\mathrm{A}}$ & $5.62 \pm 0.32^{\mathrm{AB}}$ \\
\hline T5 & $4.04 \pm 0.30^{\mathrm{B}}$ & $4.38 \pm 0.32^{\mathrm{abB}}$ & $4.81 \pm 0.36^{\mathrm{B}}$ & $5.74 \pm 0.32^{\mathrm{A}}$ \\
\hline T6 & $3.11 \pm 0.35^{\mathrm{C}}$ & $2.83 \pm 0.33^{\mathrm{cC}}$ & $5.04 \pm 0.36^{\mathrm{B}}$ & $5.78 \pm 0.32^{\mathrm{A}}$ \\
\hline
\end{tabular}

T1: Control; T2: ultrasound (US); T3: 0.1\% oregano essential oil (OEO); T4: US + 0.1\% OEO; T5: 0.3\% OEO; T6: US $+0.3 \%$ OEO; CFU: colony forming units

$\mathrm{a}, \mathrm{b}, \mathrm{c}$ : Means in the same column with different superscripts are different at $\mathrm{P} \leq 0.05$

A, B, C: Means in the same row with different superscripts are different at $\mathrm{P} \leq 0.05$

Pohlman and co-workers (1997) found that treatment with high-intensity ultrasound was not sufficient to have significant effect on microbial growth during long storage periods, although the bacterial content decreased significantly immediately after treatment. In the present study, this effect was observed for the ultrasound with $0.1 \%$ OEO treatment at day seven, when a high bacterial content was found $\left(5.39 \log _{10} \mathrm{CFU} \mathrm{ml} \mathrm{m}^{-1}\right)$. This could be attributed to the accelerated bacterial growth due to the nutrient release from muscle cells immediately after the ultrasound application. In addition, the increased growth rate during storage 
(5.74 $\log _{10} \mathrm{CFU} \mathrm{ml} \mathrm{m}^{-1}$ at day 14 ) may have been because the ultrasound intensity was insufficient to maintain the control of anaerobic bacteria. SAMS and FERIA (1991) suggested that ultrasound may promote the release of nutrients from food during refrigeration, which may be utilized by specific types of bacteria, thereby resulting in increased microbial growth. In the present study this effect could be observed in case of the ultrasound treatment (T2) and the ultrasound with $0.1 \%$ OEO (T4) during the whole storage period, when the microbial counts were statistically similar $(\mathrm{P}>0.05)$ to the control. In general, the anaerobic bacteria growth tended to increase, particularly after 21 days of storage, when all treatments show the highest bacteria growth with no difference between treatments. The combined effect of ultrasound with $0.3 \%$ OEO showed the lowest anaerobic bacterial growth during the whole storage time, therefore T6 was the best treatment for controlling the growth of anaerobic bacteria in marinated meat.

The results for LAB indicate that the initial count was similar for all treatments, except for the ultrasound with $0.3 \%$ OEO $\left(2.30 \log _{10} \mathrm{CFU} \mathrm{ml} \mathrm{m}^{-1}\right)$, which was the lowest, and it remained until day $7\left(2.41 \log _{10} \mathrm{CFU} \mathrm{ml} \mathrm{m}^{-1}\right)$. At day 14, both OEO treatments (T3 and T5) and the ultrasound with $0.3 \%$ OEO showed the lowest LAB growth. At day 21, all treatments were statistically similar ( $\mathrm{P}>0.05)$, showing no effect of treatments on LAB growth (Table 2$)$. Like the anaerobic bacteria, ultrasound alone had no significant effect on the LAB counts $(\mathrm{P}>0.05)$.

Table 2. Lactic acid bacteria count $\left(\log _{10} \mathrm{CFU} \mathrm{ml} \mathrm{m}^{-1} \pm\right.$ standard error) recovered from chicken breasts treated with ultrasound and oregano essential oil (number of replicates per treatment: 15)

\begin{tabular}{lcccc}
\hline Treatments & \multicolumn{4}{c}{ Storage time (days) } \\
\cline { 2 - 4 } & 0 & 7 & 14 & 21 \\
\hline T1 & $4.51 \pm 0.35^{\mathrm{aB}}$ & $4.47 \pm 0.41^{\mathrm{abB}}$ & $5.46 \pm 0.38^{\mathrm{aAB}}$ & $5.65 \pm 0.21^{\mathrm{A}}$ \\
T2 & $4.43 \pm 0.35^{\mathrm{aB}}$ & $4.24 \pm 0.41^{\mathrm{abC}}$ & $5.30 \pm 0.41^{\mathrm{aA}}$ & $4.97 \pm 0.21^{\mathrm{AB}}$ \\
T3 & $3.94 \pm 0.35^{\mathrm{abC}}$ & $3.42 \pm 0.41^{\mathrm{bcC}}$ & $4.34 \pm 0.38^{\mathrm{abB}}$ & $5.15 \pm 0.21^{\mathrm{A}}$ \\
T4 & $4.00 \pm 0.35^{\mathrm{abB}}$ & $5.32 \pm 0.41^{\mathrm{aAB}}$ & $5.38 \pm 0.35^{\mathrm{aA}}$ & $5.17 \pm 0.22^{\mathrm{AB}}$ \\
T5 & $3.35 \pm 0.35^{\mathrm{bC}}$ & $4.30 \pm 0.41^{\mathrm{abB}}$ & $4.74 \pm 0.35^{\mathrm{abB}}$ & $5.59 \pm 0.21^{\mathrm{A}}$ \\
T6 & $2.30 \pm 0.35^{\mathrm{cC}}$ & $2.41 \pm 0.41^{\mathrm{cC}}$ & $4.13 \pm 0.35^{\mathrm{bB}}$ & $5.39 \pm 0.21^{\mathrm{A}}$ \\
\hline
\end{tabular}

T1: Control; T2: ultrasound (US); T3: 0.1\% oregano essential oil (OEO); T4: US + 0.1\% OEO; T5: 0.3\% OEO; T6: US $+0.3 \%$ OEO; CFU: colony forming units

$\mathrm{a}, \mathrm{b}, \mathrm{c}$ : Means in the same column with different superscripts are different at $\mathrm{P} \leq 0.05$

$\mathrm{A}, \mathrm{B}, \mathrm{C}$ : Means in the same row with different superscripts are different at $\mathrm{P} \leq 0.05$

However, previous reports showed that ultrasound treatment was effective in the control of LAB (Dolatowski and Stasiak, 2002), but CAmeron (2007) found that certain species of $\mathrm{LAB}$ are resistant to ultrasound treatment, which might have been the case in the present study. In general, the treatments that included OEO facilitated greater control of microbial growth during 7 day of refrigerated storage. These results agree with other studies, which have shown that the use of OEO, either alone (ORAL et al., 2009) or in combination with other treatments such as vacuum packaging (SKANDAMIs et al., 2002), decreases the LAB content and increases the shelf life of chicken meat. In the present study, the combination of ultrasound and $0.3 \%$ OEO resulted in lower increases in the LAB content after each storage period (2.30, $2.41,4.13$, and $5.39 \log _{10} \mathrm{CFU} \mathrm{ml} \mathrm{m}^{-1}$ at $0,7,14$, and 21 day-storage, respectively). 


\subsection{Mesophilic bacteria}

The combination of vacuum packaging and OEO in fresh (CHOULIARA et al., 2007) and partially cooked chicken meat (NTZIMANI et al., 2010) is known to reduce the total bacterial count and to increase the shelf life. However, in the present study, the treatments with $0.1 \%$ OEO or ultrasound with $0.3 \%$ OEO (Table 3 ) had the best control over the growth of mesophilic bacteria (3.30 and $3.36 \log _{10} \mathrm{CFU} \mathrm{m}{ }^{-1}$, respectively) at day 0 of storage. Similarly to anaerobic bacteria and LAB, high-intensity ultrasound had no significant effect $(\mathrm{P}>0.05)$ on the growth of mesophilic bacteria at any storage time.

Table 3. Mesophile count ( $\log _{10} \mathrm{CFU} \mathrm{ml} \mathrm{m}^{-1} \pm$ standard error) recovered from chicken breasts treated with ultrasound and oregano essential oil (number of replicates per treatment: 15)

\begin{tabular}{lcccc}
\hline Treatments & \multicolumn{4}{c}{ Storage time (days) } \\
\cline { 2 - 4 } & $4.75 \pm 0.32^{\mathrm{aB}}$ & 4 & 14 & 21 \\
\hline T1 & $4.74 \pm 0.43^{\mathrm{aB}}$ & $5.87 \pm 0.34^{\mathrm{abAB}}$ & $5.89 \pm 0.23^{\mathrm{A}}$ \\
T2 & $4.79 \pm 0.32^{\mathrm{aB}}$ & $4.33 \pm 0.50^{\mathrm{abC}}$ & $5.22 \pm 0.30^{\mathrm{bAB}}$ & $5.84 \pm 0.23^{\mathrm{A}}$ \\
T3 & $3.30 \pm 0.37^{\mathrm{bD}}$ & $4.23 \pm 0.43^{\mathrm{abC}}$ & $4.92 \pm 0.30^{\mathrm{bB}}$ & $5.67 \pm 0.23^{\mathrm{A}}$ \\
T4 & $4.36 \pm 0.32^{\mathrm{aC}}$ & $5.24 \pm 0.44^{\mathrm{aBC}}$ & $6.54 \pm 0.30^{\mathrm{aA}}$ & $5.56 \pm 0.23^{\mathrm{B}}$ \\
T5 & $4.25 \pm 0.32^{\mathrm{abC}}$ & $4.43 \pm 0.53^{\mathrm{abC}}$ & $5.21 \pm 0.30^{\mathrm{bB}}$ & $6.03 \pm 0.23^{\mathrm{A}}$ \\
T6 & $3.36 \pm 0.32^{\mathrm{bC}}$ & $2.70 \pm 0.48^{\mathrm{bC}}$ & $4.78 \pm 0.30^{\mathrm{bB}}$ & $6.05 \pm 0.23^{\mathrm{A}}$ \\
\hline
\end{tabular}

T1: Control; T2: ultrasound (US); T3: 0.1\% oregano essential oil (OEO); T4: US + 0.1\% OEO; T5: 0.3\% OEO; T6: US $+0.3 \%$ OEO; CFU: colony forming units

a, $\mathrm{b}$ :Means in the same column with different superscripts are different at $\mathrm{P} \leq 0.05$

A, B, C, D: Means in the same row with different superscripts are different at $\mathrm{P} \leq 0.05$

These results do not agree with previous reports (DOLATOWSKI and STASIAK, 2002), where aerobic and mesophilic (HAUGHTON et al., 2010) bacteria could be controlled by high-intensity ultrasound. Ultrasound with $0.1 \%$ OEO did not decrease mesophilic bacteria growth, showing no effect on that bacterium group until 21 days of storage. However, when ultrasound was combined with $0.3 \%$ OEO, there was an important decrease in mesophilic growth from day 0 until day 14 of storage, though at day 21 all treatments were similar $(\mathrm{P}>0.05)$, which shows that high-intensity ultrasound also has an important effect on aerobic bacteria. These results suggest that their behaviour was similar to that of LAB and anaerobic bacteria, where lower counts were obtained with high-intensity ultrasound and $0.3 \%$ OEO (T6); the immediate effect of this treatment on aerobic bacteria and LAB can be explained by the results reported by Pohlman and co-workers (1997), and such effect had a persistent effect on mesophilic bacteria during storage. Similar to other reports (Oral et al., 2009; SHEKARForoush et al., 2007), the OEO concentration determines the levels of mesophilic bacteria during the storage of chicken breasts, since the lowest bacteria growth was observed at day 14 in T3, T5, and T6 ( $0.1 \%$ OEO, $0.3 \%$ OEO, and US with $0.3 \%$ OEO, respectively). As mentioned earlier, SAMS and FERIA (1991) suggested that treatment with ultrasound may release nutrients that promote microbial growth in some cases, which may explain the results obtained for anaerobic bacteria, LAB, and mesophilic bacteria in the present study, where ultrasound failed to reduce bacteria growth. 


\section{Conclusions}

In the present study, high-intensity ultrasound alone was not effective for controlling the growth of anaerobic bacteria, $\mathrm{LAB}$, and mesophilic bacteria during the refrigerated storage of marinated chicken meat. However, when ultrasound treatment is combined with $0.3 \%$ $\mathrm{OEO}$, the growth of those bacteria is reduced. The use of OEO as an ingredient in the marinade for vacuum-packaged chicken breasts may be a viable alternative for controlling the growth of anaerobic bacteria, LAB, and mesophiles during chilled storage. In the present study, a combination of high-intensity ultrasound and OEO was the best alternative for controlling microbial growth on marinated chicken breasts.

This research was funded by the National Council for Science and Technology in Mexico (CONACYT). Project CB-2008-01/0103933.

\section{References}

Burt, S. (2004): Essential oils: Their antibacterial properties and potential applications in foods - a review. Int. J. Food Microbiol., 94, 223-253.

CAmeron, M. (2007): Impact of low-frequency high-power ultrasound on spoilage and potentially pathogenic dairy microbes. PhD in Food Science dissertation. Faculty of AgriSciences. University of Stellenbosch. Stellenbosch. Sudafrica, Available at http://scholar.sun.ac.za/handle/10019.1/1163 (last accessed 24 March 2014).

CHENG, L.H., SoH, C.Y., Liew, S.C. \& THE, F.F. (2007): Effects of sonication and carbonation on guava juice quality. J. Food Chem., 104, 1396-1401.

Chouliara, E., Karatapanis, A., Savvaidis, I.N. \& Kontominas, M.G. (2007): Combined effect of oregano essential oil and modified atmosphere packaging on shelf-life extension of fresh chicken breast meat, stored at $4{ }^{\circ} \mathrm{C}$. Food Microbiol., 24, 607-617.

Dolatowski, Z. \& Stasiak, D. (2002): Bacterial contamination of meat and meat products after ultrasound treatment. Acta Sci. Pol. Technol. Aliment., 1, 55-65.

Govaris, A., Solomakos, N., Pexara, A. \& Chatzopoulou, P.S. (2010): The antimicrobial effect of oregano essential oil, nisin and their combination against Salmonella enteritidis in minced sheep meat during refrigerated storage. Int. J. Food Microbiol., 137, 175-180.

Haughton, P., Lyng, J., Morgan, D., Cronin, D., Noci, F., Fanning, S. \& Whyte, P. (2010): An evaluation of the potential of high-intensity ultrasound for improving the microbial safety of poultry. Food Bioprocess Tech., 5, 992-998.

Hunter, G., Lucas, M., Watson, I. \& Parton, R. (2008): A radial mode ultrasonic horn for the inactivation of Escherichia coli k12. Ultras. Sonochem., 15, 101-109.

Jørgensen, A.S., Christensen, M. \& Ertbjerg, P. (2008): Marination with kiwifruit powder followed by power ultrasound tenderizes porcine M. Biceps femoris. -in: International Conference of Meat Science and Technology, Cape Town. Sudafrica.

JunEJA, V.K. \& Friedman, M. (2007): Carvacrol, cinnamaldehyde, oregano oil, and thymol inhibit Clostridium perfringens spore germination and outgrowth in ground turkey during chilling. J. Food Protect., 70, $218-222$.

Lambert, R.J.W., Skandamis, P.N., Coote, P.J. \& Nychas, G.J.E. (2001): Mixing carvacrol and thymol at proper amounts may exert the total inhibition that is evident by oregano essential oil. Such inhibition is due to damage in membrane integrity, which further affects ph homeostasis and equilibrium of inorganic ions. J. Appl. Microbiol., 91, 453-462.

Ntzimani, A., Giatrakou, V. \& Savvaidis, I. (2010): Combined natural antimicrobial treatments (edta, lysozyme, rosemary and oregano oil) on semi cooked coated chicken meat stored in vacuum packages at $4{ }^{\circ} \mathrm{C}$ : Microbiological and sensory evaluation. Innov. Food Sci. Emerg., 11, 187-196.

Nychas, G.J.E. (1995): Natural antimicrobials from plants. -in: Gould, G.W. (Ed.). New methods of food preservation. Chapman and Hall, New York, pp. 58-89. 
Oral, N., Vatansever, L., Sezer, Ç., Aydin, B., Güven, A., Gülmez, M., Bașer, K.H.C. \& KürkçüoĞlu, M. (2009): Effect of absorbent pads containing oregano essential oil on the shelf life extension of overwrap packed chicken drumsticks stored at four degrees celsius. Poultry Sci., 88, 1459-1465.

Oussalah, M., Caillet, S. \& Lacroix, M. (2006): Mechanism of action of spanish oregano, chinese cinnamon, and savory essential oils against cell membranes and walls of Escherichia coli O157:H7 and Listeria monocytogenes. J. Food Protect., 69, 1046-1055.

Pohlman, F., Dikeman, M. \& Zayas, J. (1997): The effect of low-intensity ultrasound treatment on shear properties, color stability and shelf-life of vacuum-packaged beef semitendinosus and biceps femoris muscles. Meat Sci., 45, 329-337.

SAS (2006): Statistical Analysis Systems user's guide. Statics version 9 Cary, North Carolina, U.S.A.

SAms, A. \& Feria, R. (1991): Microbial effects of ultrasonication of broiler drumstick skin. J. Food Sci., 56, 247248.

Shekarforoush, S.S., Nazer, A.H.K., Firouzi, R. \& Rostami, M. (2007): Effects of storage temperatures and essential oils of oregano and nutmeg on the growth and survival of Escherichia coli O157:H7 in barbecued chicken used in Iran. Food Control, 18, 1428-1433.

Skandamis, P., Tsigarida, E. \& Nychas, G.J.E. (2002): The effect of oregano essential oil on survival/death of Salmonella Typhimurium in meat stored at $5^{\circ} \mathrm{C}$ under aerobic, vp/map conditions. Food Microbiol., 19, 97103.

Zhou, B., Feng, H. \& Luo, Y. (2009): Ultrasound enhanced sanitizer efficacy in reduction of Escherichia coli O157:H7 population on spinach leaves. J. Food Sci., 74, 308-313. 